\title{
Revue
}

\section{d'histoire des sciences}

\author{
TOME XLVI - 1 - JANVIER-MARS 1993
}

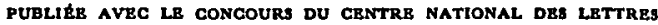

RT DU CNRS

\section{Edouard Branly et la TSF : tradition ou innovation?}

\section{SOMMAIRE}

\section{ARTICLES :}

Nicole Hulin, Edouard Branly, la formation d'un physicien parmi d'autres; Jean Cazenobe, Branly est-il l'inventeur... du tube de Branly ?; Christine Blondel, Branly et l'innovation technique : un cas d'espèce ?; Andreas Kleinert, Ferdinand Braun et les débuts de la TSF en Allemagne; Paolo Brenni, Le tube à limaille de Calzecchi Onesti et la rsf de Marconi. Quelques réflexions sur les débuts de la tsf en Italie; Dominique Pestre, Autour d'Edouard Branly : trois propositions de révision. Journée Edouard Branly (Palais de la Découverte, 9 octobre 1990 ).

\section{DOCUMENTATION :}

Christine Blondel, Bibliographie concernant Edouard Branly; Guy Giraud et Roland Faure, Du cohéreur à la science des milieux granulaires.

Direction-rédaction : Centre international de synthèse, 12, rue Colbert, 75002 Paris France

Tél. : 42975068

Administration-abonnements : Presses Universitaires de France, Departement des revues, 14, avenue du Bois-de-l'Epine, BP 90, 91003 Evry Cedex - France

Tél. : (1) 607782 o5 - Telétcopie : (I) 60792045

Télex : PUF 600474 F - CCP 130269 G Paris

Abonnements - tarif r993 (4 numéros) : France : 395 FF - Etranger : 485 FF 


\section{VICTORIAN SEXUALITIES}

Edited by Andrew Miller

This special issue of Victorian Studies (volume 36, number 3 ) brings together some of the best work being done on conceptions of sexuality in the Victorian

VICTORIAN STUDIES

Indiana

University

Press

601 N. Morton Bloomington, IN 47404

Phone:

812-855-9449

Fax:

$812-855-7931$

SUBSCRIPTIONS

(4 issues)

Individual: $\$ 25.00$

Institution: $\$ 40.00$

Foreign surface

post: $\$ 12.50$

SINGLE ISSUES

Individual: $\$ 14.70$

Institution: $\$ 21.75$ period. The essays integrate the analysis of sexuality with a wide range of interrelated topics and methods of study.

\section{CONTENTS}

Silas Marner and the Sexual Possibilities of the Commodity

Jeffery Nunokowa

"I am the Woman for Spirit":

A Working Woman's Gender Transgression in Victorian London

Camilla Tounsend

The Double Lives of Man: Narration and Identification in the Late Nineteenth-Century Representation of Ec-centric Masculinities

Ed Cohen

Technologies of Monstrosity:

Bram Stoker's Dracula

Judith Halberstam

Reimagining Masculinity in Victorian

Criticism: Swinburne and Pater

Thais Morgan 

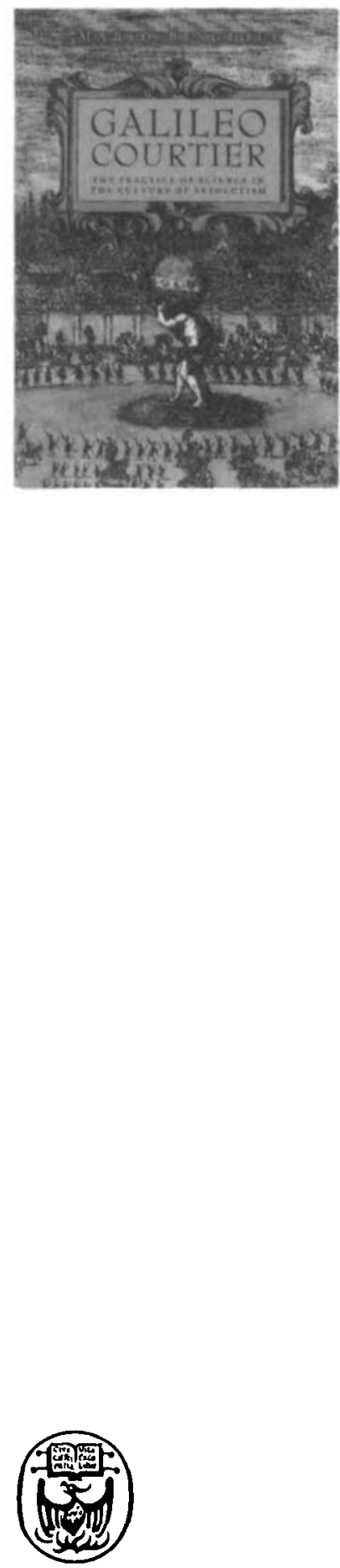

THE UNIVERSITY OF CHICAGO PRESS

5801 S. Ellis Ave.

Cbicago, IL 60637

\section{GALILEO, COURTIER}

The Prattice of Science in the Culture of Absolutism

\section{Mario Biagjoli}

"In the history of science there have traditionally been those who study the social setring of scientists and those who study the science itself. ... Biagioli's book takes the analysis one step further. ... Galileo, Courtier is the most important book on Galileo to appear in half a century."-AJbert Van Helden, Rice University

Clotb $\$ 23.95 / \$ 29.95416$ pages

Science and Its Conceptual Foundations Series

\section{MEN AMONG THE MAMMOTHS}

\section{Victorian Science and the Discovery of Human Prebistory}

\section{A. Bowdoin Van Ripor}

Van Riper recreates scientists' first arguments for human antiquity, placing these debates within the context of Victorian science. Using field notes, scientific reports, and previously unpublished letters, he shows also how the study of human prehistory brought together geologists, archeologists, and anthropologists in their first interdisciplinary scientific effort. A vivid account of how the discovery of human antiquity forced Victorians to redefine their assumptions about human evolution and the relationship of science to Christianity.

*Paper 213.50/\$16.95 288 pages

Science and Its Conceptual Foundations Series

\section{IN THE WAKE OF CHAOS}

\section{Unpredictable Order in Dynamical Systems}

\section{Stephen H. Kellert}

"A wonderfully clear and sane analysis of a tricky subject, and a powerful antidote to the contemporary vogue for chaos in popular science and critical theory.... Kellert's careful account shows how, in actual practice, order and turbulence, long term predictability and short term instability, balance each other in the physicists' picture of Nature, without betraying the fundamental program of Science. Clears away the fog admirably."-Stephen Toulmin Cloth 115.95/\$19.95 190 pages illus.

Science and Its Conceptual Foundations Series

\section{Now in Paper}

\section{FROM MINERALOGY TO GEOLOGY}

The Foundations of a Science, 1650-1830

\section{Rachel Laudan}

A comprehensive challenge to the commonly held view that geology emerged as a separate scientific specialty in early nineteenth-century Britain.

"We have waited a long while for a brand new English-language survey of the development of geology from the Scientific Revolution to its maturity as a science in the mid-nineteenth century. The wait proves to have been worthwhile, for this gap has now been filled by a volume that is assured, original, and highly stimulating. ... It will surely become the basic survey of the rise of geology."-Roy Porter, ISIS

* Paper E12.75/\$15.95 290 pages illus.

Science and Its Conceptual Foundations Series

*Clotb edition available 


\section{DIOGÈNE}

REVUE INTERNATIONALE DES SCIENCES HUMAINES fondée par ROGER CAILLOIS

No 163 - Juillet-Septembre 1993

UTOPIE ET TECHNIQUE À L'ÂGE POST-MODERNE

ROLAND FISCHER

ROLAND FISCHER

Alicia JuARrero

Klaus Bartels

GERHARD GRÔSSING

ROBERT ARTIGIANI
Présentation

Éléments d'une bistoire de la vision utopique du monde

Des racines modernes aux rbizomes post-modernes

La boîte à images digitale: le monde comme théatre informatique

L'atomisme du $X X^{e}$ siècle et sa fin

Une Renaissance $X X^{e}$ siècle? Prix et pro. messe d'un changement culturel

Diogène, Unesco,

1, rue Miollis, Paris XVe - Tél. (1) 45-68-27-34 - Télécopie (1) 40-65-94-80

L'édition française est publiée par les Éditions Gallimard, 5, rue SébastienBottin, Paris VIIe.

Les abonnements sont souscrits auprès du Service abonnements, 49 , rue de la Vanne, 92120 Montrouge ((1) 41-17-13-93) (C.C.P. 169-33 L, Paris).

Abonnement: France, $184 \mathrm{~F}$; Étudiants, $145 \mathrm{~F}$; Ettranger, $201 \mathrm{~F}$.

Le $\mathrm{n}^{0}: 56 \mathrm{~F}$. 
Membership of the Society, which normally includes a subscription to The British Joumal for the History of Science, is open to all persons approved by the Council of the Society and elected at an ordinary meeting. The annual subscription for the membership year 1994 is $£^{22.00}(\$ 45.00)$ or $£^{11.00(\$ 25.00)}$ for associate membership, which includes students at centres of higher education. There is an Introductory Offer for ordinary members who pay $\$ 17.00$ (\$35.00) for the first year. Applications for membership should be made on a form which is available from the Society's Executive Secretary at the address below. Other sterling rates may apply to overseas members.

Meetings: The Society mounts an ambitious programme of meetings. The pattern is flexible, but includes a threeday summer meeting, usually held at a different British University or Polytechnic each year. About four other meetings, lasting for between one and three days, are held during the year, sometimes devoted to a clearly defined theme or an important anniversary, and often arranged in conjunction with other scholarly societies.

The British Journal for the History of Science is the official organ of the Society. All correspondence on the contents of the Joumal should be addressed to the Editor, Dr Janet Browne, The Wellcome Institute for the History of Medicine, 183 Euston Road, London, NWI 2BE, England. Books for review should be sent to the Reviews Editor, Dr John Henry, Science Studies Unit, University of Edinburgh, 21 Buccleuch Place, Edinburgh EH8 9LN.

Advertising: Contact the Journals Advertising Manager, Cambridge University Press, The Edinburgh Building, Shaftesbury Road, Cambridge CB2 2RU.

Other publications: BSHS Monograph Series is designed to allow the publication of monographic studies in the history of science quickly and cheaply. All correspondence on the subject of monographs, and any new suggestions for titles, should be sent to the Series Editor, Dr P. Weindling, Wellcome Unit for the History of Medicine, 45-47 Banbury Road, Oxford OX2 6PE, England. Monographs are available to members at a special price, post-free from the Society's Executive Secretary. Non-members may obtain them through bookshops, or post-free from the Executive Secretary. Titles are as follows:

2. The Letters of Georges Cuvier: A Summary Calendar. Ed. by Dorinda Outram. 1980. $£ 4.50 / \$ 10.00(£ 3.50 / \$ 8.00$ to members).

3. Rationality and Ritual: The Windscale Inquiny and Nuclear Decisions in Britain. By Brian Wynne. 1982. $£ 7.00 / \$ 15.00$ ( $5.00 / \$ 11.00$ to members).

4. The Royal Society and Its Fellows 1660-1700: The Morphology of an Early Scientific Institution. By Michacl Hunter. Reprint with additional material (expected early 1994).

5. Francis Bacon's Natural Philosophy: A New Source. A Transcription of Manuscript Hardwick $72 A$ with Translation and Commentary. By Graham Rees, assisted by Christopher Upton. $1984 . £^{7.90 / \$ 17.00}\left(£^{5.60 / \$ 12.00}\right.$ to members).

6. Archives of the British Chemical Industry, 1750-1914:A Handlist. By Peter J. T. Morris and Colin A. Russell. Contributing editor John Graham Smith. 1988. $\AA^{14.50 / \$ 31.00}\left(f^{9.00 / \$ 19.00}\right.$ to members).

7. Index to the Scientific Correspondence of John William Dawson. By Susan Sheets-Pyenson. 1992. $£ 20.00 / \$ 44.00$ (f12.00/\$26.00 to members).

8. Science and Nature: Essays in the History of the Environmental Sciences. Ed. by Michael Shortland. 1993. $£ 10.00 /$ $\$ 19.00\left(\ell^{8.00 / \$ 15.00}\right.$ to members).

Each year, the Society publishes a List of Theses in History of Science in British universities. This is available free to members, and at $\ell^{3.00}(\$ 6.00)$ to non-members on request to the Executive Secretary. Standing orders are accepted from members or non-members who wish to receive the list regularly.

The Society's Newsletter, an informal publication edited by Dr Frank A. J. I. James, RICHST, The Royal Institution, 21 Albemarle Street, London WIX 4BS, appears in January, May and September each year. It is free to members, $£ 6.00$ (\$12.00) for institutions and non-members. The Society's Education Section also has a regular Newsletter, Education Forum, edited by Dr Isobel Falconer, Lumbo Farmhouse, St Andrews, Fife KY16 8NS.

Administrative business of the Society is handled by The Executive Secretary, Wing-Commander G. Bennett, 31 High Street, Stanford in the Vale, Faringdon, Oxfordshire SN7 8L.H. The Society is registered in England as a Limited Company (No. 562208) and is a Registered Charity (No. 258854).

Copying: This journal is registered with the Copyright Clearance Center, 27 Congress Street, Salem, MA 01970. Organizations in the USA who are also registered with the CCC may therefore copy material (beyond the limits permitted by sections 107 and 108 of US copyright law) subject to payment to CCC of the per-copy fee of $\$ 5.00$. This consent does not extend to multiple copying for promotional or commercial purposes. Code 0007-0874/94 $\$ 5.00+.00$.

ISI Tear Sheet Service, 3501 Market Street, Philadelphia, Pennsylvania 19104, USA, is authorized to supply single copies of separate articles for private use only.

Organizations authorized by the Copyright Licensing Agency may also copy material subject to the usual conditions.

For all other use, permission should be sought from Cambridge or the American branch of Cambridge University Press.

Back volumes are obtainable as follows: Volumes 1-23: Wing-Commander G. Bennett, 31 High Street, Stanford in the Vale, Faringdon, Oxon SN7 8LH. For volume 24 onwards, apply to Cambridge University Press. 


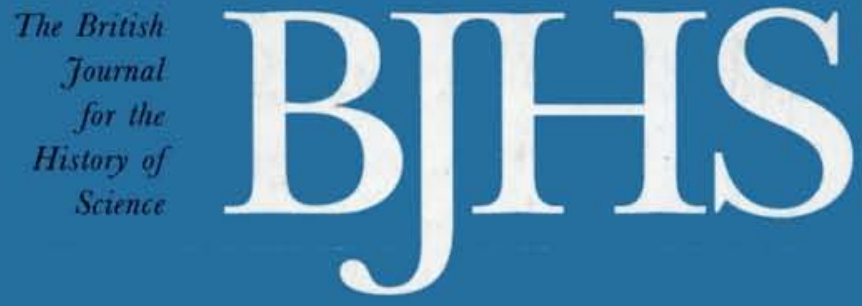

Volume 27

Part I No. 92

\section{March 1994}

1. Editorial Note

3 Making a meal of the big dish: the construction of the Jodrell Bank Mark 1 radio telescope as a stable edifice, $1946-57$ JON AGAR

23 British women who contributed to research in the geological sciences in the nineteenth century

MARY R. S. CREESE AND THOMAS M. GREESE

55 'Nullius in verba' and 'nihil in verbis': public understanding of the role of language in science

CLIVE SUTTON

65 Colonial pride and metropolitan expectations: the British Museum and Melbourne's meteorites

A. M. LUGAS, P. J. LUGAS, THOMAS A. DARRAGH AND SARA MAROSKE

89 Kepler's invention of the second planetary law WILLIAM H. DONAHUE

\section{Essay review}

103 The Piltdown man

TIM MURRAY

\section{Notes}

I05 The final mission of HMS Beagle: clarifying the historical record NATHAN DUBOWSKY AND SCOTT MICHAEL. DUBOWSKY

113 The 'Einstein-Laue' discussion W. SGHRÖDER AND H.-J. TREDER

115 Book reviews

127 Books received

Published for The British Society for the History of Science

by Cambidge University Press

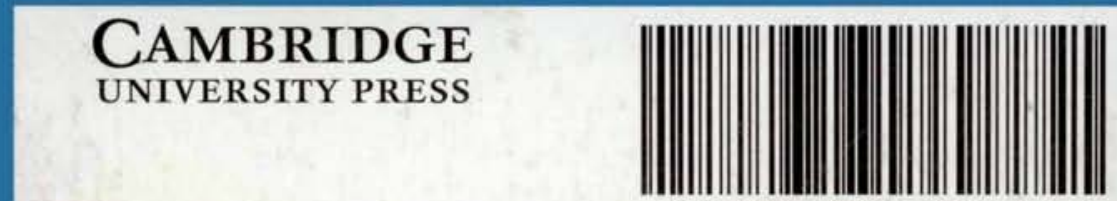

